\title{
NON-CITIZENS IN LATVIA: IS IT A REAL PROBLEM?
}

\begin{abstract}
Following the restoration of independence in 1991, Latvia has introduced restrictive citizenship strategy involving citizenship only to those who had it before the Soviet occupation, and to their descendants. As a result, about one-third of the population in Latvia-the former citizens of the Soviet Union who had immigrated to Latvia during the Soviet period-received the status of 'non-citizen'. In the 1990s, political discourse on the citizenship policy dominated in Latvia. Exclusive Citizenship Act was criticized by international institutions, including the UN, EU, OSCE and CoE. As a result of international pressure Latvia has introduced appropriate amendments to facilitate access to citizenship for non-citizens. Non-citizens and stateless in Latvia represent $11.8 \%$ and $0.01 \%$ of the population, respectively, which is more than 252 thousand residents of Latvia. It means that non-citizenship phenomenon has not been resolved completely. A few Latvian regulations restrict non-citizens and stateless to participate in elections, occupy public positions and offices, and travel. This article addresses the problem of non-citizenship as a second matter of concerns in Latvian domestic policy. While limitations for non-citizens implicate their political, economic and social status, Latvian authority is far from granting citizenship to non-citizens in 'zero option' procedure.
\end{abstract}

Key words: citizenship; non-citizens; statelessness; naturalization; Latvia
ALEKSANDRA KUCZYŃSKA-ZONIK Instytut Europy Środkowo-Wschodniej, Lublin E-mail: kuczynska.a@gmail.com

CITATION: Kuczyńska-Zonik, A. (2017). Non-citizens in Latvia: Is It a Real Problem? Sprawy Narodowościowe. Seria nowa, 2017(49). https://doi.org/10.11649/sn.1438

This work was supported by the Polish Ministry of Science and Higher Education (Grant no. DN/MOB/121/IV/2015). No competing interests have been declared.

This is an Open Access article distributed under the terms of the Creative Commons Attribution 3.0 PL License (creativecommons.org/licenses/by/3.0/pl/), which permits redistribution, commercial and non-commercial, provided that the article is properly cited. (C) The Author(s) 2017.

Publisher: Institute of Slavic Studies, Polish Academy of Sciences 
Streszczenie

Po odzyskaniu niepodległości Łotwa w 1991 roku wprowadziła restrykcyjną strategię obywatelstwa, polegającą na przywróceniu obywatelstwa jedynie tym osobom, które posiadały je przed okupacją sowiecką, oraz ich potomkom. W wyniku tego około jednej trzeciej populacji na Łotwie - byłych obywateli Związku Radzieckiego przybyłych na Łotwę w okresie sowieckim - otrzymało status „nieobywatela”. W latach dziewięćdziesiątych kwestia obywatelstwa zdominowała dyskurs polityczny na Łotwie, a wyłączająca ustawa o obywatelstwie była krytykowana przez różne instytucje międzynarodowe, w tym ONZ, UE, OBWE i Radę Europy. Międzynarodowa presja spowodowała, że Łotwa wprowadziła stosowne poprawki, ułatwiając dostęp do obywatelstwa dla nieobywateli. Obecnie nieobywatele stanowią 11,8\%, a bezpaństwowcy - niecałe 0,01\% populacji, co wynosi łącznie ponad 252 tys. mieszkańców Łotwy. Oznacza to, że problem braku obywatelstwa nie został rozwiązany całkowicie. Niektóre regulacje ograniczające prawa nieobywateli i bezpaństwowców odnoszą się do prawa wyborczego, możliwości zajmowania pewnych stanowisk i urzędów oraz podróży. Artykuł poświęcony jest zjawisku braku obywatelstwa na Łotwie, które obecnie nie jest przedmiotem większego zainteresowania władz Łotwy. Regulacje ograniczające prawa nieobywateli wpływają na ich status polityczny, ekonomiczny i społeczny, jednak podjęcie decyzji o automatycznym obywatelstwie dla nieobywateli przez władze Łotwy jest mało prawdopodobne.

Słowa kI uczowe: obywatelstwo; nieobywatele; bezpaństwowcy; naturalizacja; Łotwa

\section{INTRODUCTION}

\section{T} he 1954 UN Convention relating to the Status of Stateless Persons and the 1961 UN Convention on the Reduction of Statelessness are the key international conventions addressing statelessness (United Nations High Commissioner for Refugees [UNHCR], 2016). The first one establishes the legal definition of a stateless person as someone who is not recognized as a national by any state and it establishes minimum standards of treatment for stateless people in respect to a number of rights including the right to education, employment, documents, housing and identity (Convention relating to the Status of Stateless Persons, 1954). Further, the 1961 Convention aims to prevent statelessness and reduce it over time (Convention on the Reduction of Statelessness, 1961). Latvia has signed both conventions, and implemented them by introducing 2004 Citizenship Law. Those regulations are applicable directly to 178 stateless residents in Latvia but do not apply to more than 252,000 non-citizens residing in Latvia (The Office of Citizenship and Migration Affairs, 2016). The intention of Latvian authorities was to distinguish non-citizens from stateless in domestic law and to ensure a wider range of rights to non-citizens as a result of their historical, political and social specifics in Latvia.

An attempt to rebuild the national identity in Latvia following the collapse of the Soviet Union explains this extraordinary citizenship strategy. Thirteen out of fifteen former Soviet republics chose 'zero option' for residents to receive citizenship in the independent states. All registered and having the legal right residents could stay in the country offi- 
cially and apply for citizenship. Only Latvia and Estonia followed a restrictive strategy. Citizenship was granted only to those who had it before 16/17 June 1940, the date indicating the beginning of the Soviet occupation, and to their descendants. Russian-speakers, mostly ethnic Russians, Ukrainians and Belarusians who find themselves in these countries as a result of the Soviet migration policy received 'non-citizen' status (Lat. Nepilsoni; Est. Kodakondsuseta isik). Latvia and Estonia assumed non-citizenship was a temporary status that allowed residents to be naturalized at any time after fulfillment of particular requirements. Restrictive legislation resulted from continuing distrust of ethnic Latvians and Estonians to Russian-speaking immigrants accused of fifty years of Soviet occupation (1940-1991), ${ }^{1}$ separatist tendencies and need for rapid assimilation of Russian-speakers. Both Latvia and Estonia sought to rebuild nation-state on the interwar tradition and European identity basis (Matonyte, 2013; G. Smith, 2016). While Estonian integration policy proceeded more smoothly (Feldman, 2005; Kalmus, 2003; D. J. Smith, 2015, p. 5), Latvia insisted more on assimilative language policy by reducing Russian language in public space and limiting Russian schools.

The aim of this article is to promote a deeper understanding of non-citizenship question in Latvia and the implication of this status to political, economic and social position of non-citizens in the state. The main argument is that while several actions were taken to dynamize process of naturalization in the 1990s, currently Latvian authorities have no idea how to solve the problem. While Russian-speakers do not constitute any danger to the state sovereignty, Latvia refuses to gratify them by Latvian citizenship automatically. On the other hand, today there are still a considerable number of non-citizens who are unwilling to naturalize due to a variety of internal and external factors. It is the intention of this article to continue a discussion about the necessity to deepen political integration and social cohesion between citizens and non-citizens. In order to address this issue, the argument in this paper is structured as follows. First, Latvian citizenship strategy in historical perception is defined. The second part is dedicated to the question how the number of non-citizens was reduced since the independence. Afterwards, political, economic and social rights for non-citizens are presented to prove their relatively low status in Latvia.

\section{'RETURN TO THE PAST'}

The Soviet migration policy has changed ethnic demography in Latvia dramatically. Minority residents of the interwar period representing mainly Germans, Poles, Jews and Swedes were replaced by Russians, Belarusians and Ukrainians. The number of ethnic Latvians decreased from $73 \%$ of the population in 1935 to $52 \%$ in 1989 (Figure 1).

An idea of 'ethnic democracy' involving restrictive rules of naturalization was applied to restore interwar demographic situation of Latvia and to consolidate society in the nation-state (Sasse, 2010). On 15 October 1991, the Supreme Council of Republic of Latvia renewed citizens' rights and circumscribed the fundamental principles of naturalization in Latvia (Supreme Council Resolution, 1991), and afterwards it adopted Citizenship Act on 22 June 1994 (Citizenship Law, 1994), slightly amended in 1995. They followed the ius

1 From 1941 to 1944 the Baltic states were occupied by Nazi Germany.

2 Following the independence, the national policy of the Baltic states called 'return to the past' or 'reconstruction of the nation' was to confirm their European identity in ideological, geographical, legal, political, historical, economic, cultural, religious, and social spheres. 
Figure 1. Latvian ethnic population (\%)

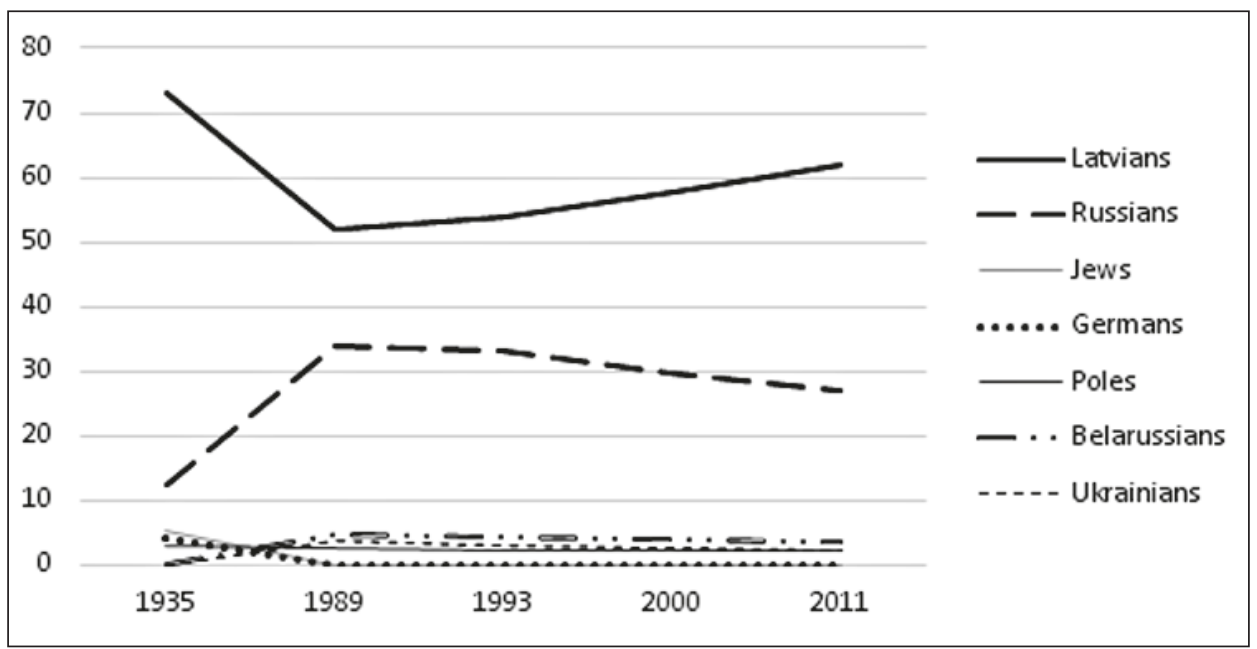

sanguinis principle. According to those above Latvian citizenship was granted to residents of Latvia who had it before 17 June 1940, and to their descendants. About one-third of Latvian population, in particular former citizens of the Soviet Union was refused Latvian citizenship. Citizenship Law was based on the principles of the interwar Citizenship Law adopted in 1919. The aim of that legislation was to preserve the state continuity and legal tradition. Apart from the naturalization procedure the law established a new status of 'non-citizen' absent in hitherto international legislation. It referred to 'citizens of non-existent state'. In addition, the law indicated a group of residents who could not be admitted to Latvian citizenship. It included those who:

1. have, by unconstitutional methods, acted against the independence of the Republic of Latvia;

2. have propagated fascist, chauvinist, national-socialist, communist or other totalitarian;

3. are officials of foreign state;

4. serve in the foreign armed forces, internal military forces, security service or police;

5. have been employees, informers, agents of KGB;

6. have been members of the communist party (Citizenship Law, 1994).

Furthermore, Citizenship Law assumed the number of naturalized in each year, ${ }^{3}$ although it was canceled under the international pressure (Morris, 2003). The 'window' system was applied which limited the age groups allowed to naturalize each year. It gave priority to those born in Latvia over those born outside Latvia, and priority to the younger age group in each category over the older ones (Elsuwege, 2008, p. 73; Kelley, 2010, pp. 87-89; Krūma, 2010, p. 9). The referendum held in October 1998 eliminated the 'windows' system (Krūma, 2015).

According to Latvian population register from 31 March 1993, 1,729,740 citizens and 714,980 non-citizens resided in Latvia. The register excluded 161,456 members of the Soviet armed forces still stationed in Latvia, residents in army houses (KECH) and military

\footnotetext{
3 It was assumed that since 2000 only $0.1 \%$ of the population might be naturalized annually according to demographic and economic situation as well as the state development.
} 
bases or with 'connection to the army' (Helsinki Watch, 1993). In contrast to registered non-citizens with square seals in their passport, non-registered former Soviet citizens received a special round stamp in their documents. It should be mentioned that the agreement on the withdrawal of the Soviet troops from Latvia was finally signed on 30 April, 1994 and stated the withdrawal before 31 August 1994. Russia was allowed to use Latvian military base in Skrunda where more than 700 Russian members of civil service resided until 1998 (Jeffries, 2004, pp. 179-187).

On 12 April 1995 the law on citizens of the former USSR status was adopted. All permanent residents in Latvia were divided into four groups:

1. citizens;

2. aliens (citizens of other states);

3. non-citizens (citizens of the former USSR);

4. stateless.

Non-citizens were granted relatively wide spectrum of rights and freedom. They could reside permanently in Latvia ex lege and move freely within and outside the country. Until 1998 they could use the Soviet document which was afterwards replaced by an alien passport. Stateless with permanent residence in Latvia enjoyed the same social rights as non-citizens. Furthermore, they could apply for naturalization.

\section{DECREASE IN NUMBER OF NON-CITIZENS}

Restrictive law on citizenship was intended to restore the legal status and ethnic demography of Latvian interwar period. This process was the most intensive in the 1990s when 130,000 non-citizens emigrated from Latvia. According to the Central Bureau of Statistics (2016), between 1991-1995, 168,230 individuals left Latvia, mainly non-citizens and former Soviet Army soldiers and their families. Between 1996-2011, the number of non-citizens declined as a result of effective naturalization. In recent years, the number of non-citizens is reduced mainly due to mortality (Table 1).

Table 1. Non-citizens in Latvia

\begin{tabular}{|l|l|l|l|l|l|}
\hline & $\mathbf{2 0 1 1}$ & $\mathbf{2 0 1 2}$ & $\mathbf{2 0 1 3}$ & $\mathbf{2 0 1 4}$ & $\mathbf{2 0 1 5}$ \\
\hline Total & 296,619 & 275,604 & 267,559 & 253,640 & 242,259 \\
\hline$\%$ & 14,3 & 13,5 & 13,2 & 12,7 & 12,2 \\
\hline
\end{tabular}

Source: Central Bureau of Statistics.

At the beginning of Latvian naturalization policy the number of applications for naturalization turned out to be much lower than expected. According to data of the Naturalization Board, during 1995-1998 only 15,853 individuals applied for naturalization and the number of successful applicants was 11,431 (Krūma, 2015). The dynamics of naturalization peaked in the late 1990s and at the beginning of 2000, and afterwards between 2004-2006 (Figure 2). A few citizenship rules were liberalized before the UE accession as the EU Commission had recognized them as too restrictive. Since 1999 the 'window' system was abolished and amendments legitimized non-citizens to occupy several professions where high level of the state language was required such as firefighters, phar- 
macists and veterinarians. Partially refinanced or free language courses were introduced and media information campaigns promoted naturalization process were launched.

Dynamics in naturalization between 2004 and 2006 resulted from the EU accession. Non-citizens were afraid of their status in UE. Most of them benefited from Latvian citizenship which facilitated to move to UE. Naturalized respondents clarified they need to belong to the state and be secured by the state, vote, travel, find a better job or own land (Zepa, 2003). However dynamics of naturalization has been decreasing recently. Only 939 individuals were granted by Latvian citizenship in 2014 (Latvian Centre for Human Rights, 2015). While since their introduction, the Latvian language and history exams have been simplified, the naturalization fee has been reduced for low-income, unemployed, retired persons, and abolished for politically_repressed and disabled persons, orphans and persons from social care institutions (Ministry of Foreign Affairs of the Republic of Latvia, 2015), today there are still a considerable number of non-citizens who are unwilling to naturalize due to a variety of internal and external factors (Krūma, 2015). Non-citizens who reject Latvian citizenship explain they enjoy relatively high status providing social care and find it difficult to pass the application process and be naturalized. Furthermore, since June 2008, they can travel to Russia freely without visa permission. ${ }^{4}$ They deny passing language and history exams verifying their state knowledge, where they have lived for several years. Others hope to be granted Latvian citizenship automatically or consider adopting a citizenship of another country.

Figure 2. Dynamics of naturalization in Latvia

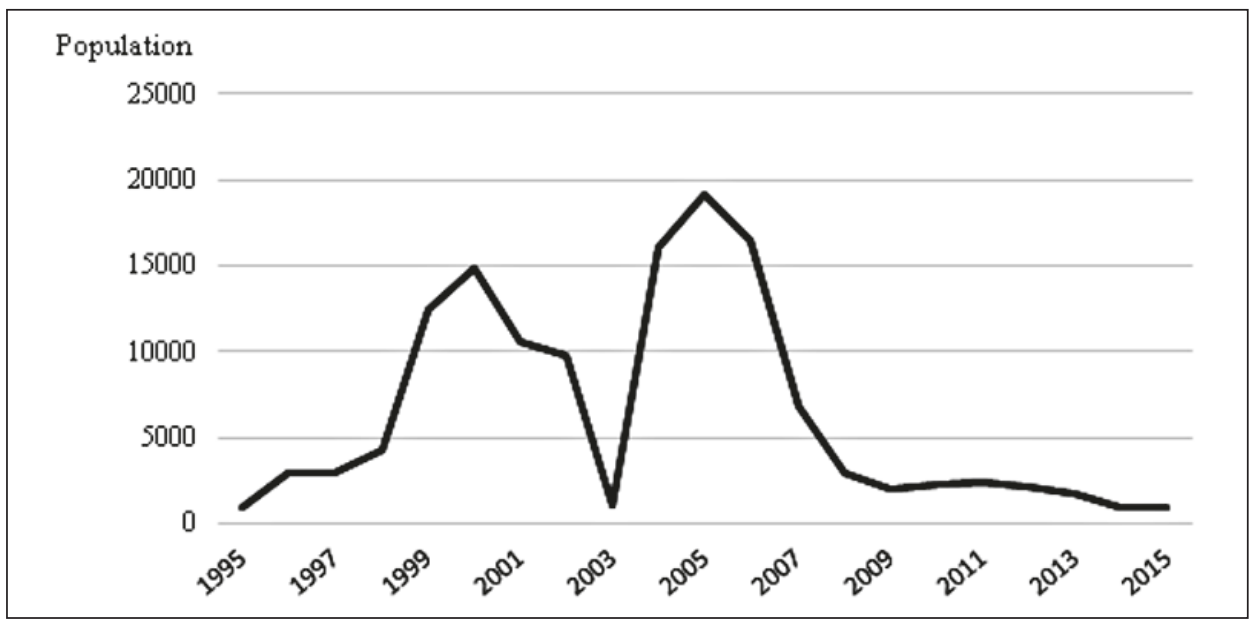

According to 1994 Citizenship Law, children whose at least one parent is a citizen of Latvia automatically receive Latvian citizenship. Children born from non-citizens may obtain citizenship of Latvia in the procedure of naturalization of their parents before they reach the age of 15 , or since they are at least 15 in naturalization procedure individually. Since 2004 amendments to law, non-citizen children born in independent Latvia may receive Latvian citizenship if their parents express such a wish (The Office of Citizenship and Migration Affairs, 2016). While initially the application form from both parents was

4 Since August 2016, it does not apply only to individuals born following the collapse of the USSR. 
required, since 2013 one parent's application form is enough to obtain Latvian citizenship by a non-citizen child. Due to a simple procedure it can be done while child registration. Official statistics suggest that the number of children registered as citizens has increased in the wake of the recent amendments and the number of non-citizen children has decreased (Krūma, 2015; European Network on Statelessness, 2015). In 2014, 85\% children whose parents are non-citizens were registered as citizens, against 56\% in 2013 (Latvian Centre for Human Rights, 2016). While some parents are for non-citizen status for their children due to visa-free travel to Russia, some of them are not informed enough to register a child as a citizen of Latvia in a simple procedure. Today more than 7,000 children in Latvia still have no citizenship of any state (Latvian Centre for Human Rights, 2016). Noteworthy, in many cases non-citizen status is inherited.

Popularity of Russian citizenship among non-citizens in Latvia has been increasing significantly only after an economic crisis in Latvia (2008-2010) due to economic and social reasons (social security and lower retirement age) (Table 2).

Table 2. Resident population by citizenship in Latvia

\begin{tabular}{|l|l|l|l|l|l|l|l|}
\hline & \multicolumn{2}{|c|}{2000} & \multicolumn{2}{c|}{2011} & \multicolumn{2}{c|}{2013} & \multicolumn{1}{c|}{2015} \\
\hline & \multicolumn{1}{|c|}{ Total } & \multicolumn{1}{c|}{$\%$} & \multicolumn{1}{c|}{ Total } & \multicolumn{1}{c|}{$\%$} & \multicolumn{1}{c|}{ Total } & \multicolumn{1}{c|}{$\%$} & \multicolumn{1}{c|}{ Total } \\
\hline Total & 2.381 .715 & 100 & 2.070 .371 & 100 & 2.023 .825 & 100 & 1.986 .096 \\
\hline Latvian & 1.771 .967 & 74 & 1.728 .213 & 83 & 1.708 .411 & 84 & 1.687 .663 \\
\hline Russian & 19.236 & 0,8 & 33.805 & 1,6 & 36.147 & 1,7 & 41.886 \\
\hline Ukrainian & 1.514 & $<0,1$ & 2.484 & 0,1 & 2.345 & 0,1 & 2.716 \\
\hline Belarussian & 791 & $<0,1$ & 1.677 & $<0,1$ & 1.611 & $<0,1$ & 1.861 \\
\hline UE (except Latvia) & 2.788 & 0,1 & 5.885 & 0,3 & 5.596 & 0,3 & 6.805 \\
\hline Non-citizens & 582.175 & 24 & 296.619 & 14 & 267.559 & 13 & 242.259 \\
\hline Stateless & 1.433 & $<0,1$ & 210 & $<0,1$ & 187 & $<0,1$ & 188 \\
\hline
\end{tabular}

Source: Central Statistical Bureau of Latvia, 2015.

\section{POLITICAL, ECONOMIC AND SOCIAL RIGHTS FOR NON-CITIZENS IN LATVIA}

Non-citizens of Latvia are not stateless persons. They enjoy protection under the law both in Latvia and while living or travelling abroad. They can have permanent residence in a foreign country while retaining all rights and privileges, to travel freely and to return back to Latvia at any time (Ministry of Foreign Affairs of the Republic of Latvia, 2015). They may be members of political parties in Latvia and since January 2007, they have right to visafree travel within the EU. While non-citizens have the same social guarantees as Latvian citizens there are several differences in political and economic rights between citizens and non-citizens in Latvia. The most significant one refers to the lack of the right to vote and to work in the civil service or occupy posts not only directly related to national security but also in a private sector including state officials, diplomatic and consular corps, judges, lawyers, notaries, policemen, soldiers. Non-citizens do not have the right to own a land. They do not enjoy protection under the national minority legislation. 
The restrictions do not apply to naturalized individuals, although some examples of discrimination show that even naturalized Russian-speakers have limited access to high public professions (Grigas, 2014). While more Latvians work as judges, lawyers or prosecutors, non-citizens with low level of state language knowledge have limited access to such professions as technicians, engineers, computer scientists, designers, and architects. That is why it negatively affects their social and economic status. Today, similar to the Soviet period, many of them work in building companies or transport, mainly in the private sector (Milne, 2014).

Non-citizens desire Latvian citizenship but their status does not determine their sense of belonging to Latvia directly. Opinion polls show that $74.6 \%$ Russian-speakers in Latvia declare loyalty to the state. While individuals over 65 years of age express the largest level of loyalty (81.1\%), several of them are non-citizens. Young people (57.6\%) present the lowest level of loyalty and very few of them are non-citizens. In contrast, while $63.8 \%$ of Russian-speakers recognize themselves as Latvia's patriots, the proportion of citizens of Latvia $(69.1 \%)$ is significantly higher than non-citizens $(56.4 \%)$. The percentage of Russian-speakers with Latvian citizenship who are proud of it is higher than non-citizens enjoy their status (63.4\% and 50\%, respectively). Neither Russian-speaking citizens nor noncitizens demonstrate interest in politics of the state (SKDS, 2014). Citizens, however, are more socially active than non-citizens in sense of participating in public meetings, openly manifesting their opinions or being members of social organizations.

Overwhelming majority of non-citizens (80\%) admit they do not expect to obtain the citizenship of Latvia in the near future. Only $11 \%$ support it, in contrast to $32 \%$ of young non-citizens in the age of 18-24 plans to apply for the naturalization procedure. The reasons for the low interest are as follows:

1. relatively high status of non-citizens and the number of rights already granted;

2. a lack of knowledge of the Latvian language;

3. age;

4. easier requirements for traveling to Russia for non-citizens;

5. disappointment at not having been granted citizenship automatically;

6. plans to apply for Russia's (or other state's) citizenship (SKDS, 2014).

\section{CONCLUSIONS}

Presenting a deeper understanding of non-citizenship question in Latvia the article reveals that although several actions were taken to dynamize processes of naturalization today Latvia does not have a constructive strategy how to solve the problem of non-citizen status introduced 25 years ago (Kuczyńska-Zonik, 2016) as a result of ideological, political, historical, and socio-economic reasons. Under the criticism of international institutions including UN, EU, OSCE, CoE, Helsinki Watch and Amnesty International more restrictive citizenship legislations were liberalized before the UE accession. Although following 2004, the problem has not been solved completely, and the international community condemned Latvia's policy towards non-citizens as a EU's double standard.

Although PE, CoE, UN High Commissioner for Human Rights as well as OSCE High Commissioner on National Minorities have monitored Latvia citizenship policy (Institute on Statelessness and Inclusion, 2014; Reine, 2007) and several recommendations have 
been put forward to adjust Latvian law to international regulations, no systematic and serious abuses of human rights in the area of minority rights have been uncovered. Latvia may but does not have to apply to such recommendations.

Latvian citizenship policy is not effective enough and naturalization process has not been reducing the number of non-citizen completely. In Latvia, the percentage of secondand third-generation non-citizens, whose parents or grandparents are non-citizens, is still disquieting. A similar situation concerns Estonia where 34\% and $19 \%$ non-citizens are second- and third-generation non-citizens, respectively. They enjoy good state language proficiency and support state values but are excluded from political life still not having right to vote (Nimmerfeldt, 2009; Vetik et al., 2015).

Today, a debate on military security and social cohesion (Birka, 2016; Lamoreaux, 2014; Muižnieks, 2010; Thornton \& Karagiannis, 2016) has replaced citizenship discourse in Latvia. Non-citizen status is a second matter of concern for Latvian authorities and even for non-citizens who are less interested in the process of naturalization and politics in general. Young non-citizens see more benefits from Latvian citizenship than their parents or grandparents (European Network on Statelessness, 2015). Noteworthy, Latvian citizenship is only an instrument to better social and political status, easy access to education, profession and mobility in UE, but not a determinant of state loyalty and patriotism.

Both Latvia and Estonia continue debates on simplification of the naturalization procedure by introducing a 'zero option' for non-citizens. While Latvia recognizes the idea as a threat to its social cohesion and national identity, 'zero option' is more likely in Estonia, where the number of non-citizens is lower and social tolerance and multicultural openness are wider. Despite initial restrictive ethnic policy it was consequently liberalized which brought an effective integration strategy in Estonia (Feldman, 2005; Kelley, 2010, pp. 94-115). Many amendments were introduced in Estonia, such as automatic citizenship to children born from non-citizens, launched in 2016. Latvian proponents believe children of non-citizens born in the independent Latvia should receive citizenship a priori without expressing such a need. In contrast, Latvian officials and conservative political parties are against it, indicating non-citizens' 'democratic right' to choose the status for their children. Another question is whether or not naturalized individuals may belong to national and ethnic minorities or enjoy minority protection in Latvia. It is believed that Latvia is not ready for such a step.

\section{BIBLIOGRAPHY}

Birka, I. (2016). Expressed attachment to Russia and social integration: The case of young Russian speakers in Latvia, 2004-2010. Journal of Baltic Studies, 47(2), 219-238. https://doi: 10.1080/01629778.2015.1094743

Central Bureau of Statistics. (2015). Demography 2015. Riga.

Central Bureau of Statistics. (2016). Retrieved 8 August 2017, from http://www.csb.gov.Iv/ Citizenship Law. (1994). Retrieved 8 August 2017, from http://www.mfa.gov.Iv/en/policy/society-integration/citizenship-in-latvia/citizenship-law

Convention on the Reduction of Statelessness. (1961). Retrieved 2 June 2017, from http://www.unhcr.org/ibelong/wp-content/uploads/1961-Convention-on-the-reductionof-Statelessness_ENG.pdf 
Convention relating to the Status of Stateless Persons. (1954). Retrieved 2 June 2017, from http://www.unhcr.org/ibelong/wp-content/uploads/1954-Convention-relating-tothe-Status-of-Stateless-Persons_ENG.pdf

Elsuwege, P. van. (2008). From Soviet Republics to EU Member States: A legal and political assessment of the Baltic States' accession to the EU. Leiden: Brill. https://doi. org/10.1163/ej.9789004169456.i-585

European Network on Statelessness. (2015). Ending childhood statelessness: A study on Latvia. Working Paper, 2015(7). Retrieved 2 June 2017, from http://www.statelessness.eu/sites/www.statelessness.eu/files/Latvia_0.pdf

Feldman, G. (2005). Culture, state, and security in Europe: The case of Citizenship and Integration Policy in Estonia. American Ethnologist, 32(4), 676-694. https://doi. org/10.1525/ae.2005.32.4.676

Grigas, A. (2014, November 28). The new generation of Baltic Russian speakers. EurActive. Retrieved 2 June 2017, from https://www.euractiv.com/section/europe-s-east/ opinion/the-new-generation-of-baltic-russian-speakers/

Helsinki Watch. (1993). Violations by the Latvian Department of Citizenship and Immigration. Helsinki Watch, 5(19). Retrieved 2 June 2017, from https://www.hrw.org/sites/ default/files/reports/LATVIA100193.pdf

Institute on Statelessness and Inclusion. (2014). The world's stateless. Oisterwijk: Wolf Legal Publishers (WLP). Retrieved 2 June 2017, from http://www.institutesi.org/ worldsstateless.pdf

Jeffries, I. (2004). The countries of the Former Soviet Union at the turn of the twenty-first century: The Baltic and European States in transition. London: Routledge.

Kalmus, V. (2003). 'Is interethnic integration possible in Estonia?': Ethno-political discourse of two ethnic groups. Discourse \& Society, 14(6), 667-697. https://doi. org/10.1177/09579265030146001

Kelley, J. G. (2010). Ethnic politics in Europe: The power of norms and incentives. Princeton, NJ: Princeton University Press. https://doi.org/10.1515/9781400835652

Krūma, K. (2010). Integration and Naturalisation tests: The new way to European Citizenship. Centre for Migration Law, Radboud University, Nijmegen Netherlands.

Krūma, K. (2015). Country report on citizenship law: Latvia. Florence: European University Institute.

Kuczyńska-Zonik, A. (2016, October 17). 25 lat statusu nieobywatela na Łotwie. Przegląd Battycki. Retrieved 2 June 2017, from http://przegladbaltycki.pl/3413,25-statusunieobywatela-lotwie.html

Lamoreaux, J. W. (2014). Acting small in a large state's world: Russia and the Baltic states. European Security, 23(4), 565-582. https://doi.org/10.1080/09662839.2014.948862

Latvian Centre for Human Rights. (2015). Minority rights in Latvia: 25 years after the adoption of The Copenhagen Document, in the light of Ljubljana Guidelines and Bolzano/Bozen Recommendations. Retrieved 2 June 2017, from http://www.osce.org/ pc/195301?download=true

Latvian Centre for Human Rights. (2016). Submission to the Universal Periodic Review. Retrieved 2 June 2017, from http://cilvektiesibas.org.Iv/media/attachments/26/01/ 2016/lchr_upr24_Iva_e_main.pdf

Matonyte, I. (2013). Political reconsideration of the Soviet past: Attitudes and actions of the Lithuanian elites. Baltic Region, 2013(3), 86-97. https://doi.org/10.5922/2079-85552013-3-9 
Milne, R. (2014, March 30). Latvia's Russians express dissatisfaction. Financial Times. Retrieved 2 June 2017, from https://www.ft.com/content/562950b0-b661-11e3-b230$00144 f e a b d c 0$

Ministry of Foreign Affairs of the Republic of Latvia. (2015). Basic facts about citizenship and language policy of Latvia and some sensitive history-related issues. Retrieved 2 June 2017, from http://www.mfa.gov.Iv/en/policy/society-integration/citizenship-inlatvia/citizenship-policy-in-latvia/basic-facts-about-citizenship-and-language-policy-oflatvia-and-some-sensitive-history-related-issues

Morris, H. M. (2003). EU enlargement and Latvian citizenship policy. Journal on Ethnopolitics and Minority Issues in Europe (JEMIE), 2003(1). Retrieved 2 June 2017, from http://www.ecmi.de/fileadmin/downloads/publications/JEMIE/2003/nr1/Focus1-2003_ Morris.pdf

Muižnieks, N. (Ed.). (2010). How integrated is Latvian society?: An audit of achievements, failures and challenges. Riga: University of Latvia Press.

Nimmerfeldt, G. (2009). Identificational integration of second generation Russians in Estonia. Studies of Transition States and Societies (STSS), 1(1), 25-35.

Reine, I. (2007). Protection of stateless persons in Latvia: Seminar on Prevention of Statelessness and Protection of Stateless Persons within the European Union. European Parliament Committee on Civil Liberties, Justice and Home Affairs. Retrieved 2 June 2017, from http://www.europarl.europa.eu/hearings/20070626/libe/reine_en.pdf

Sasse, G. (2010). Ukraine: The role of regionalism. Journal of Democracy, 21(3), 99-106. https://doi.org/10.1353/jod.0.0177

SKDS. (2014). Piederības sajūta Latvijai: Mazākumtautību Latvijas iedzìvotāju aptauja. Riga: SKDS.

Smith, D. J. (2015). Minority rights, multiculturalism and EU enlargement: The case of Estonia. Journal on Ethnopolitics and Minority Issues in Europe, 14(4), 79-113.

Smith, G. (2016). The Baltic States: The national self-determination of Estonia, Latvia and Lithuania. Basingstoke: Springer.

Supreme Council Resolution. (1991). Retrieved 2 June 2017, from http://www.venice. coe.int/webforms/documents/?pdf=CDL(1991)034-e

The Office of Citizenship and Migration Affairs. (2016). Latvijas iedzīvotāju sadalījums pēc valstiskās piederïbas. Retrieved 2 June 2017, from http://www.pmlp.gov.Iv/lv/assets/ documents/statistika/IRD2016/ISVP_Latvija_pec_VPD.pdf

Thornton, R., \& Karagiannis, M. (2016). The Russian threat to the Baltic States: The problems of shaping local defense mechanisms. The Journal of Slavic Military Studies, 29(3), 331-351. https://doi.org/10.1080/13518046.2016.1200359

United Nations High Commissioner for Refugees (UNHCR). (2016). Retrieved from http:// www.unhcr.org/

Vetik, R., Kallas, K., Kruusvall, J., Saar, E., Helemäe, J., Leppik, C., ... Ubakivi-Hadachi, P. (2015). Estonian society monitoring 2015. Retrieved 2 June 2017, from http://www. kul.ee/sites/kulminn/files/kokkuvoteeim_2015_en.pdf, 10.12.2016

Zepa, B. (2003). Citizenship, official language, bilingual education in Latvia: Public policy in the last 10 years. Retrieved 2 June 2017, from http://pdc.ceu.hu/archive/00001163/01/ bilingvalalzglitiba10g.pdf 